\title{
LOCAL TOURISTS OF RUHUNA (YALA) NATIONAL PARK: ZONAL VISITATION, TRAVEL COST AND WILLINGNESS TO PAY
}

\author{
U. M. I. R. K. Weerasinghe, Dayánanda Kariyawasam \& Mangala De Zoysa \\ Faculty of Agriculture, University of Ruhuna
}

Ruhuna (Yala) National Park, a strict nature reserve which lies on the southern coast of Sri Lanka, covers 97,878 hectares of land. The park comprises of secondary forest where many species of mammals, avifauna, reptiles and birds are living in substantial numbers. The Park has achieved the international reputation. Evidently, all categories of some 100,000 tourists, 70 percent of which are loca tourists visit the Park annually. Tourism in a sanctuary is both nature based and sustainable, and sustainability incorporates environmental, socio-cultural and economic dimensions. There should be a control of supply-oriented management securing the environmental and economic benefits. The public interest and enthusiasm in the Park could be used not only to market the product but also to conserve the resources. Hence, the study attempted to analyze the local demand of the tourists for Ruhuna National Park wit the view of improving Ruhuna National Park as an attractive tourist's destination.

The local demand of the tourists for Ruhuna National Park is measured as zonal visitation rate, travel cost, and their willingness to pay. The highest visitation rate is recorded from Badulla (5.6) while the lowest rate is recorded from Matale (2.1). The visitors from Matale have the highest total travel cost (Rs. 732.50). Hambantota visitors spend Rs. 115.04 as the total travel cost. However, the multiple regression analysis shows that the visitation rate with income, age, educational level and tolal travel cost excluding the visitors from Matara and Hambantota districts, is highly correlated $\left(\mathrm{r}^{2}=0.935\right)$. However, the age is significantly correlated with visitation rate while total travel cost has a significant ncgative correlation with the visitation rate. According to the local visitors, the willingness to pay per person per year is calculated as Rs. 116.41

Proceedings of the Eighth Annual Forestry and Environment Symposium 2002 of the Department of Forestry and Environmental Science, University of Sri Jayewardenepura, Sri Lanka 